International Journal of Child, Youth and Family Studies (2018) 9(1): 31-53

DOI: http://dx.doi.org/10.18357/ijcyfs91201818118

\title{
"OTHERWISE I MIGHT NOT HAVE BEEN ABLE TO COPE AT ALL": A RESEARCH PROJECT ON THE RESIDENTIAL CARE OF CHILDREN AND ADOLESCENTS
}

\author{
Silke Birgitta Gahleitner, Christina Frank, Katharina Gerlich, \\ Heidemarie Hinterwallner, Martha Schneider, and Hermann Radler
}

\begin{abstract}
Today, residential care for children and adolescents is under scrutiny to a far greater degree than was the case only 20 years ago. Psychosocial trauma approaches - especially in the German-speaking countries - have become far more widespread over the past few years. But how do they in fact work? This was the subject of a recent Austrian research project that looked for "examples of best practice" in a mixed-methods study. The quantitative part of the study comprised symptom-oriented questionnaires. Within the qualitative part of the study semistructured interviews as well as group discussion were conducted. This article reflects some specific results of the study in the light of theoretical aspects of the psychosocial trauma approach; in Germany, this is also called the "traumapedagogical approach".
\end{abstract}

Keywords: psychosocial trauma work, residential care, mixed-method designs

Silke Birgitta Gahleitner $\mathrm{PhD}$ (the corresponding author) is a professor at the Alice Salomon Hochschule Berlin - Arbeitsbereich Psychosoziale Diagnostik und Intervention, Alice-SalomonPlatz 5, D-12627 Berlin, Germany. Email: sb@gahleitner.net

Christina Frank Mag. is a predoctoral researcher at Donau-Universität Krems - Department für Psychotherapie und Biopsychosoziale Gesundheit, Dr.-Karl-Dorrekstraße 30, A-3500 Krems an der Donau, Austria. Email: christina.frank@ donau-uni.ac.at

Heidemarie Hinterwallner Mag. is a predoctoral researcher at Donau-Universität Krems Department für Psychotherapie und Biopsychosoziale Gesundheit, Dr.-Karl-Dorrekstraße 30, A3500 Krems an der Donau, Austria. Email: heidemarie.hinterwallner@donau-uni.ac.at

Katharina Gerlich $\mathrm{PhD}$ is a researcher at Donau-Universität Krems - Department für Psychotherapie und Biopsychosoziale Gesundheit, Dr.-Karl Dorrekstraße 30, A-3500 Krems an der Donau, Austria. Email: katharina.gerlich@donau-uni.ac.at

Martha Schneider Mag. is a predoctoral researcher at Donau-Universität Krems - Department für Psychotherapie und Biopsychosoziale Gesundheit, Dr.-Karl-Dorrekstraße 30, A-3500 Krems an der Donau, Austria. Email: martha.schneider@donau-uni.ac.at

Hermann Radler is a member of management at Therapeutische Gemeinschaften Wien, Grinzingerstraße 30, A-1190 Wien, Austria. Email: h.radler@t-gemeinschaften.org 
International Journal of Child, Youth and Family Studies (2018) 9(1): 31-53

In 2014, 29,476 children and adolescents in Austria received support from the public child care services, and 10,810 children and adolescents were placed in so called "full care", with almost half of them in foster families, and the rest in family-like residential care homes. Studies have shown that over $60 \%$ of these young people in full care have youth psychiatric disorders requiring treatment, approximately $80 \%$ have experienced trauma, and approximately $60 \%$ have been multiply traumatised (Schmid, 2007, 2010). Under the new Austrian Child and Youth Welfare Act all services provided by the child and youth welfare authorities must fulfil the requirements of academic expert opinions and methods that are recognised in the relevant areas of professional expertise (Kinder- und Jugendhilfegesetz, § 17 Sub-Section 1 and $\S 51$ SubSection 2).

To date the main focus of enquiry has been the state of health of the clientele (see, for example, the WHO Youth Health Survey: Richter, Hurrelmann, Klocke, Melzer, \& RavensSieberer, 2008; and the recent KIGGS Study carried out by the Robert Koch Institute: Hölling, Schlack, Petermann, Ravens-Sieberer, \& Mauz, 2014); there have also been numerous outcomeoriented studies on residential care and more generally on child and youth welfare services (Macsenaere \& Esser, 2012). These studies have revealed that there has been a sharp increase in the need for psychosocial welfare services in the German-speaking countries. In the reality of their daily practice professionals are confronted with the fact that their tasks are becoming "more difficult" (Pauls, 2012). Children and adolescents with severe and very severe psychosocial distress situations and crises confront professionals with sustained challenges. A central concept in this context is the "new morbidity" (see Haggerty, Roghmann, \& Pless, 1975; for new morbidity in children and adolescents see the KIGGS study: Thyen \& Scriba, 2007).

For some years psychosocial trauma care plans have been becoming more widespread. The goal is to help social work professionals fulfil their demanding tasks both by providing further and continuing training, and by creating viable structures in the institutions. A research project in Austria that was conceived as a collaborative undertaking between a university ${ }^{1}$ and an institution providing care set out to take a closer look at the effects of this attachment- and trauma-sensitive approach in the context of a residential care institution run by the child and youth welfare authorities. Thus attention was directed particularly to the "most difficult" young people, including them in a joint search for "best-practice examples" in a mixed-methods study.

Following a brief introduction to the basic elements of the psychosocial trauma approach or trauma-pedagogical approach, and to the program employed by the facility being studied, we shall present some specific results of the study and then compare them with existing aspects of the theory of the trauma-pedagogical approach.

\footnotetext{
${ }^{1}$ This research project was carried out from 2013 to 2016 as a collaboration between the Therapeutische Gemeinschaften e. V. and Donau University Krems, Department for Psychotherapy and Biopsychosocial Health (Gahleitner, Frank, Hinterwallner, Gerlich, \& Schneider, 2016). All quantitative results and cited interview passages have been taken from this report. Details of the methodological procedures are also given.
} 
International Journal of Child, Youth and Family Studies (2018) 9(1): 31-53

\section{The Basic Trauma-Pedagogical Elements of the Program of the Facility Studied}

\section{Excursus: Trauma and Disorganised Attachment}

Psychological trauma is a "vital experience of discrepancy between threatening situational factors and the individual's coping strategies" (Fischer \& Riedesser, 1998, p. 79) that occurs as a result of a harrowing event and is associated with loss of control, horror, and fear (of death). The extent of the traumatisation is dependent on the type, circumstances, and duration of the event and the stage of development of the victim at the time it occurs. The circumstances also include whether there were protective factors before, during, or after the traumatisation. However, one central protective factor - stable attachments — is missing for many children and adolescents who have experienced the traumatic events of violence and abuse in childhood. In fact, violence towards children occurs mainly in close (attachment) relationships; that is, within the family.

It is especially these early and long-lasting traumata that occur in the children's intimate social environments that lead to the phenomena of psychological fragmentation and disintegration and fundamentally shatter their sense of safety and security in the world. The lack of availability of stable attachment figures not only increases the risk of trauma, but is itself a trauma risk and makes it more difficult to cope with life later on. A destructive vicious circle develops. Disorganised behaviours arising from disturbed attachment are in fact found more frequently in children who have been traumatised, abused, or neglected in early childhood (Schleiffer \& Gahleitner, 2010; Ziegenhain \& Fegert, 2012).

Many children living in residential institutions, in particular, show symptoms of highly insecure attachment or other attachment disorders and severe traumatisation (Solomon \& George, 2011; Van IJzendoorn, Schuengel, \& Bakermans-Kronenburg, 1999). The changes are manifested at all levels, including the neurophysiological structures of the children and adolescents (Perry \& Pollard, 1998; Yehuda, 1998). The psychoanalyst, pediatrician, and psychiatrist John Bowlby (1973), who repeatedly encountered neglect and separation and also trauma in early childhood in socially disadvantaged children (see also Gahleitner, KatzBernstein, \& Pröll-List, 2013), made similar observations. Based on his work with families living in poverty, Bowlby developed attachment theory in his trilogy Attachment and Loss (1969, 1973, 1980).

\section{The Therapeutische Gemeinschaften}

The Therapeutische Gemeinschaften [Therapeutic Communities] are a non-profit organisation that was founded in 1999. The aims of this charitable association concern bringing up children and adolescents in family-like structures individually, continuously, and without relationship break-ups. Male children and adolescents requiring special treatment due to social and psychological difficulties live in group care homes. The children can be as young as preschool age at intake; care ends at the age of 16. Children with behavioural or other types of 
International Journal of Child, Youth and Family Studies (2018) 9(1): 31-53

psychological disturbances are accepted for care. Most of the children come from Lower Austria, Vienna, and Burgenland. In specially justified cases, children from anywhere in Austria can be admitted.

The services provided by the Therapeutische Gemeinschaften include residential care in sociotherapeutic residential communities and external supported living. The Therapeutische Gemeinschaften also offer in-house school education and an in-house advice centre for parents. In the Therapeutische Gemeinschaften, "full child-care" (Austrian Federal Child and Youth Welfare Act 2013, §19: Ger.: B-KJHG, §19) is carried out. All the children and adolescents in care have experienced severe stress. The goal of the Therapeutische Gemeinschaften is to help them establish, with their participation, a basis for leading a life outside of residential care. The four main focuses of the work are:

- work on the clients' personal problems;

- social learning through interaction in small groups;

- reflection on their different roles in life, including confrontation with maladaptive behaviours; and

- Psychodynamic Imaginative Trauma Therapy for Children and Adolescents (PITT-KID; Krüger \& Reddemann, 2007).

The work in the Therapeutische Gemeinschaften focuses on relationships. While the clients' histories have an influence on the carers' actions, the main emphasis is on the pedagogical activities in the here-and-now. The small groups in which the young people live together have immense potential. Through their participation in the development of these groups (including being taken into the group, getting to know one another, finding one's position) the residents can learn how to handle relationships. Group processes are considered by the carers to be a central sphere of learning.

Many of the children and adolescents have difficulties at school. For these clients there is a special learning programme that is carried out mainly in in-house teaching sessions. In addition to in-house teaching and therapeutic care, the clients are also able to receive psychotherapy offsite. The services offered are completed by a wide range of leisure time activities for the children and also work with their parents, which is considered to be a central element. The after-care programme is designed to support the young people as they find their way out into adult life.

The Therapeutische Gemeinschaften consider it to be their task to create a healing social environment for children and adolescents in their care; one that is participative in nature, but also enables the clients to learn high levels of independence, organisational ability, and to take responsibility for themselves. The care workers endeavour to show the children and adolescents alternative ways to behave. However, the heart of the pedagogical and therapeutic process in the Therapeutische Gemeinschaften is an attitude of working with the residents, using trauma- 
International Journal of Child, Youth and Family Studies (2018) 9(1): 31-53

pedagogical principles, to seek the sources of their behavioural disturbances and address them dialogically, both in daily life in the group and in therapy with residents and their significant others.

\section{The Effective Factors of Psychosocial Trauma Work According to the Programme}

Attachment and relationship. In child and youth welfare services it is well known that healing and beneficial processes essentially arise in human encounters and relationship activities (here and in what follows, where not indicated otherwise, see Gahleitner, 2016b). A closemeshed network of positive and reliable relationships, woven with the aid of a satisfactory socialisation structure and sound knowledge about the respective problems (AK TWG, 2009), denotes a care facility where best practices are followed. Positive attachments create a feeling of inner security and thus provide a basis for fundamental emotional and cognitive control processes (Ziegenhain \& Gloger-Tippelt, 2013).

In traumatised children and adolescents, inner security is lacking, and emotional and cognitive control processes are therefore severely limited or impaired. As a rule, children and adolescents who are admitted to residential youth care institutions have had consistently negative relationship experiences. However, even in this situation "hopeful attachments" (Hart, 2006) can form, providing a basis for confronting the past traumatic experiences with new positive experiences in a process of "re-socialisation". Such attachments are therefore the basis for all successful pedagogical activities.

However, such a process cannot be successful unless all the professional care workers are informed about the basic principles of attachment theory and aspects of traumatic experiences, stress, and potential coping strategies (Gahleitner, 2011). For some time attachment theory was criticised for being too individual-centred and too ethologically- and norm-oriented (see, in particular, Beck-Gernsheim, 1981). Today, however, attachment theory has taken on a substantially more social orientation (for a recent review see Drieschner, 2011); it can also be understood as a developmental theory in the sense that it is concerned with broadening experiences of interaction and includes societal and historical perspectives.

Trauma-pedagogical approaches focus particularly on establishing a "fabric of psychological security" (Grossmann \& Grossmann, 2004, p. 612). The residue of successful and less successful interactions thus becomes the basis for organising the entire subsequent development — including the whole period spent in residential youth care - if the traumapedagogical approach is correctly used by the care staff. It is therefore not surprising that research has repeatedly shown that such "corrective emotional experiences" have a decisive influence on the success of professional care (Alexander \& French, 1946; Cremerius, 1979; Grawe, 2004; Orlinsky, Grawe, \& Parks, 1994).

The pedagogical and therapeutic milieu. A positive milieu can evolve on the basis of sound attachment work. At conferences and in discussions among colleagues the term 
International Journal of Child, Youth and Family Studies (2018) 9(1): 31-53

"therapeutic milieu" is frequently wrongly understood to mean the effect of psychotherapeutic interventions alone, and not, for example (as actually meant in milieu intervention programmes) healing or beneficial processes that take place in ordinary life (see. here and in what follows, where not indicated otherwise, Gahleitner, 2016a). The main focus is on "the 23 hours outside the psychotherapy session - because that is when and where most of the milieu is", as Trieschmann emphasised as early as 1969 (Trieschmann, Whittaker, \& Brendtro, 1969, p. 1).

Redl (1971), one of the founders of the programme, demanded early on that all interventions should be specific and tailored to fit the respective child; and also collaborative with the participation of the child. The "therapeutic milieu" can thus be seen as an umbrella term covering all aspects of an overall pedagogical and therapeutic system (Becker, 2005), a "democratic residential community that is low on repression ... and draws its stability essentially from the personal bonds that have been reflected upon therapeutically" (Müller, 1999, p. 406).

Böhnisch (1994, 2008, p. 439f.) gives four dimensions of a "pedagogical milieu":

- a personal understanding dimension, in which the children and adolescents are accepted and understood, and "new milieus" become alternatives for "old" ones;

- an activating dimension, in which new resources are brought together;

- a pedagogical and interactive dimension, in which a beneficial social climate is created by a shared positive milieu; and

- a dimension that is oriented towards infrastructure and provides the necessary networking and a structural framework.

In addition to attachment theory, the theraputic milieu must also include elements of network theories and theories of social support (Laireiter, 2009; Nestmann, 2010; Röhrle, 2001).

These considerations are very similar to recent trauma-pedagogical conceptualisations (e.g., Weiß, 2016). An intervention with children and adolescents that is oriented towards them not only works on the relationship dyad but also shapes the way the clients conceptualize their past, present, and future relationships. In work with children and adolescents it is important that the interventions be successfully institutionally embedded in child and adolescent welfare services (see Gahleitner \& Homfeldt, 2012, 2016).Creating successful attachment processes sounds very simple, but has wide-ranging implications as regards both content and practical implementation.

Making exploration and new development possible. Children and adolescents who have been exposed to desolate circumstances at an early age are existentially dependent on social resources capable of guaranteeing stable psychosocial security as a positive counteractive experience (Keupp, 1997). In this way clients' development can progress on the basis of extensive attachment work and the provision of a pedagogical and therapeutic milieu. "The youth 
workers, especially, and other important persons, including those outside of the close nuclear family, play a decisive role" (Grossmann \& Grossmann, 2001, p. 51).

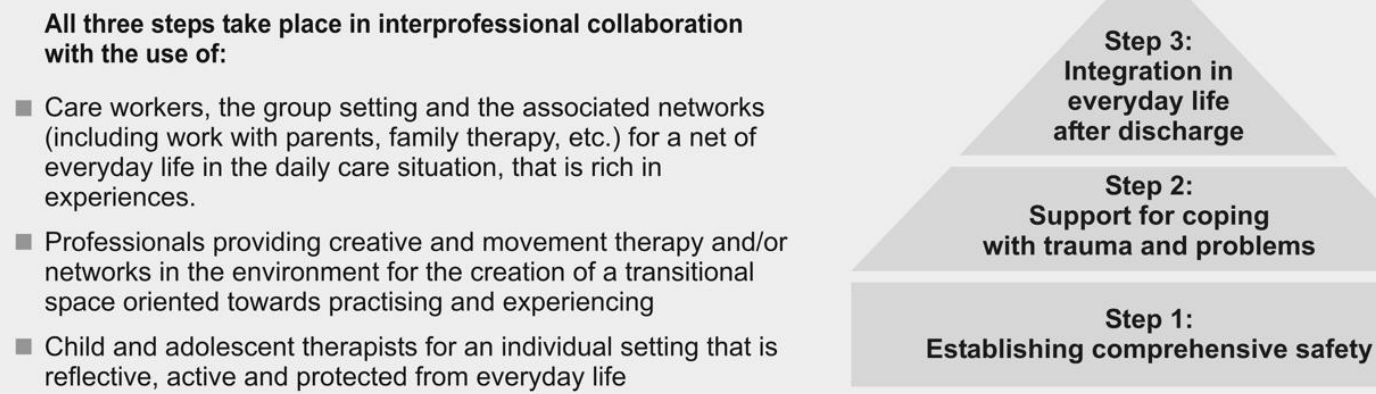

- Care workers, the group setting and the associated networks (including work with parents, family therapy, etc.) for a net of everyday life in the daily care situation, that is rich in experiences.

- Professionals providing creative and movement therapy and/or networks in the environment for the creation of a transitional space oriented towards practising and experiencing

- Child and adolescent therapists for an individual setting that is reflective, active and protected from everyday life

Step 3:

Integration in

everyday life

after discharge

Step 2:

Support for coping

with trauma and problems

Step 1:

Establishing comprehensive safety

Creative space for practising
Daily living with educational support
Protected individual setting

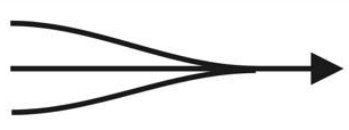

Step 1:

Establishing comprehensive safety

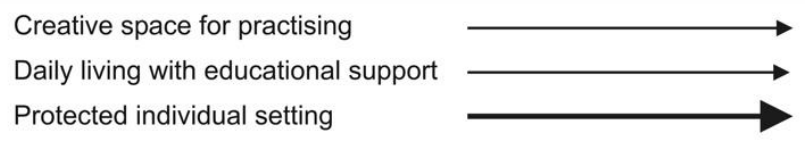

Step 2:

Support for coping

with trauma and problems

Creative space for practising

Daily living with educational support

Protected individual setting

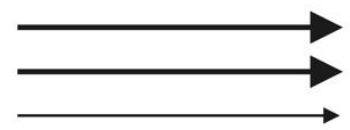

Step 3:

Integration in

everyday life

after discharge

Figure 1. Psychosocial interventions for traumatised children and adolescents (Gahleitner, 2011, S. 95; see also, for example, Butollo, Krüsmann, \& Hagl, 1998; Lebowitz, Harvey, \& Herman, 1993; Wintersperger, 2006).

Successful relationship situations - irrespective of whether they occur in therapy, in residential care, or in foster care - thus develop step by step into a fundamental scheme of emotional, social, and cognitive development. Such processes are also termed "mentalisation processes" (Fonagy, Gergely, Jurist, \& Target, 2002). If sequences of experiences that are emotionally important — as seen from the standpoint of attachment theory — are empathetically supported at an early age, "inner emotional states ... [become] 'available' to the child on the level of conscious linguistic discourse" (Grossmann \& Grossmann, 2004, p. 419). However, in order to be able to develop in this way children who have had traumatic experiences need as many "emotionally corrective experiences" (Brisch, 1999, p. 94) as possible. These alternative experiences can include "protective island experiences" (Gahleitner, 2005, p. 63); that is, spaces in which the children feel understood and can again and again find their way to constructive 
International Journal of Child, Youth and Family Studies (2018) 9(1): 31-53

opportunities for change arising out of everyday situations. For this to happen, what is needed are not only individual dyadic relationships, but also, as mentioned above, broad networks of relationships that extend right into constructive network settings between institutions that reintegrate clients into everyday life. This system of networks is also included in a tried and proven model of coping with trauma, one that was originally developed for psychotherapy but has now also been elaborated for trauma-pedagogical work (see Figure 1; for a summary for the field of youth care work, see Gahleitner, 2011).

Kühn (2009) and Lang (2009) speak of the "safe place" as a framework for encounter. The safe place is a concept very similar to that of the protective island experience (Weiß, 2016). In such spaces corrective experiences can occur step by step in "emotionally oriented dialogues", and new abilities and skills can be developed (Kühn, 2009, p. 31). The concept of selfempowerment that Weiß (2016) has further elaborated and brought into trauma-pedagogical work builds on these ideas. A new awareness of self can also lead to stabilisation of abilities such as representations of the body, expectations of self-efficacy, social skills, and capacities for emotional and sensory perception and emotional regulation.

\section{Methods and Results}

\section{Research Methods}

The research question for this project was: How do adolescents, their parents, and their carers perceive the process of residential care for children and adolescents, and what is their judgement of its success? Using an exploratory approach to outcome research (Otto, Albus, Polutta, Schrödter, \& Ziegler, 2007; see also Eppler, Miethe, \& Schneider, 2011; Sommerfeld \& Hüttermann, 2007), a reconstructive, qualitative social research approach was chosen as a complement to quantitative research methods with their focus on generalisable results on parameters of living circumstances and environment (Pauls, 2006). The qualitative approach provides access to subjective interpretations (Bock \& Miethe, 2010).

Problem-centred interviews and group discussions (Witzel, 1982, 2000) were selected for this qualitative procedure. The adolescents were asked to recount their life histories (see Sgolik $\&$ Buchholz-Graf, 2010). The main focus was on their perceptions of their experiences and behaviour and how they had changed during their time in the Therapeutische Gemeinschaften. A total of 20 participants were interviewed in individual interviews and group discussions. The staff caring for the adolescents, the management staff, and the adolescents' parents were also included in this process. All interviews, and in particular those conducted with the adolescents, were analysed with the aid of Mayring's (2000, 2002) content analysis with a casecontextualising intermediate step (see Mayring \& Gahleitner, 2010).

The goal of the quantitative part of the study was to provide insight into the extent to which the Therapeutische Gemeinschaften are effective in their work with traumatised children and adolescents. To this end, diagnostic measures were employed, including some already used 
International Journal of Child, Youth and Family Studies (2018) 9(1): 31-53

by the Therapeutische Gemeinschaften, and measures such as the Child Behavior Checklist (CBCL; Döpfner, Schmeck, \& Berner, 1994), which has been already validated (see Döpfner et al., 1994 for an overview of the psychometric properties of this test). A detailed discussion of the individual measures is included in the research report (Gahleitner, Frank, Hinterwallner, Gerlich, \& Schneider, 2016). An outcome-oriented questionnaire on case development with which good results had already been obtained in previous studies (e.g., AK-TWG, 2009) was also employed. The investigation period extended from autumn 2013 (t1) to spring 2016 (t3). Within this period questionnaires were filled in approximately every third month $(\mathrm{t} 2)$.

\section{Results}

As mentioned above, the Therapeutische Gemeinschaften provides care for children and adolescents with serious problems; that became evident in this study. A total of $77.42 \%$ of the children and adolescents had already been in residential psychiatric treatment, and an almost equally large percentage had also been in other residential youth welfare institutions. A total of $67.14 \%$ were on medication. Figure 2 shows the most frequent reasons for admitting the children and adolescents to the Therapeutische Gemeinschaften. This diagram also explains the high rate of traumatisation among these children and adolescents in residential treatment.

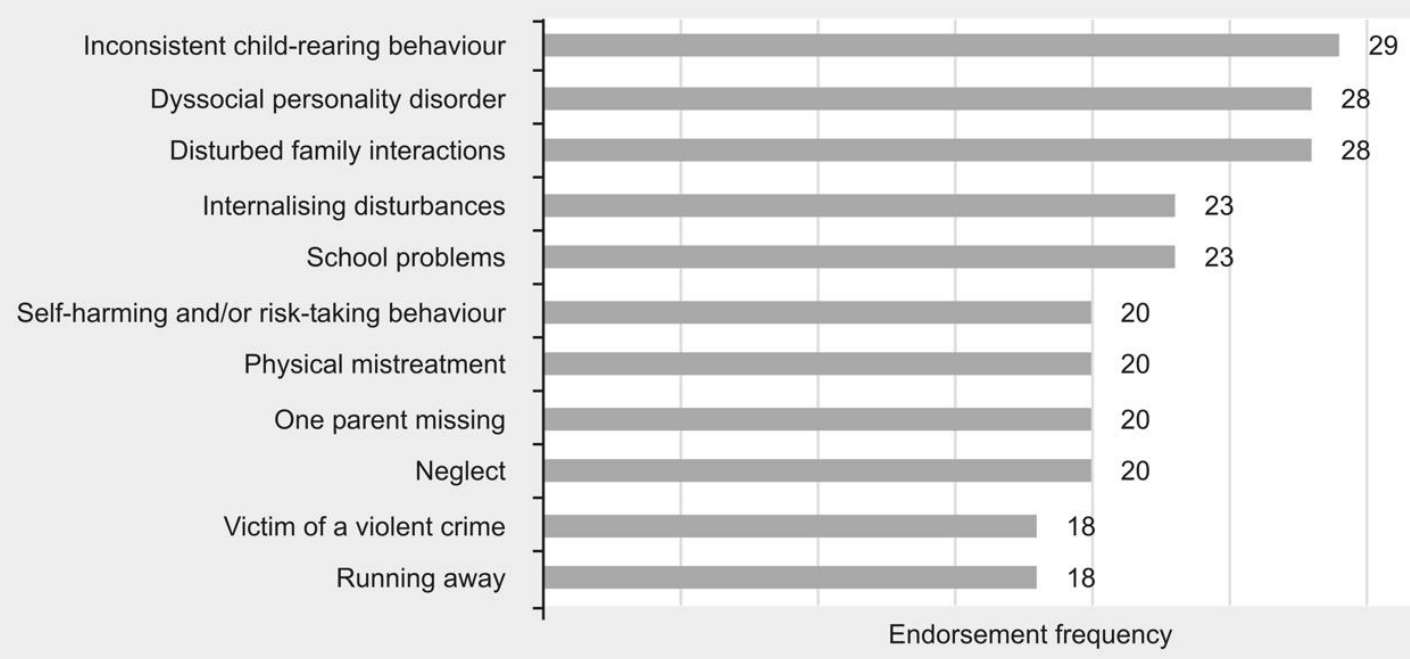

Figure 2. The 11 most frequently reported reasons for admission to the Therapeutische Gemeinschaften (one or more answers possible). 
International Journal of Child, Youth and Family Studies (2018) 9(1): 31-53

The children and adolescents in care possessed resources of their own. The most prominent of these were their cooperative behaviour $(83.8 \%)$ and their positive relationships with staff (93.33\%). In addition, only a small fluctuation in the number of children in this institution was found, which is a mark of quality that stands in contrast to the numerous youth care institutions in which the clients had previously been placed. Stability of placement helps the children to prevent attachment disruptions. These outcomes are underpinned by the comprehensive services and activities that the institution offers to its clients, including activities that structure their day, experiential adventure-based and therapeutic interventions, regular counselling sessions with both the children and their parents (see Figure 3).

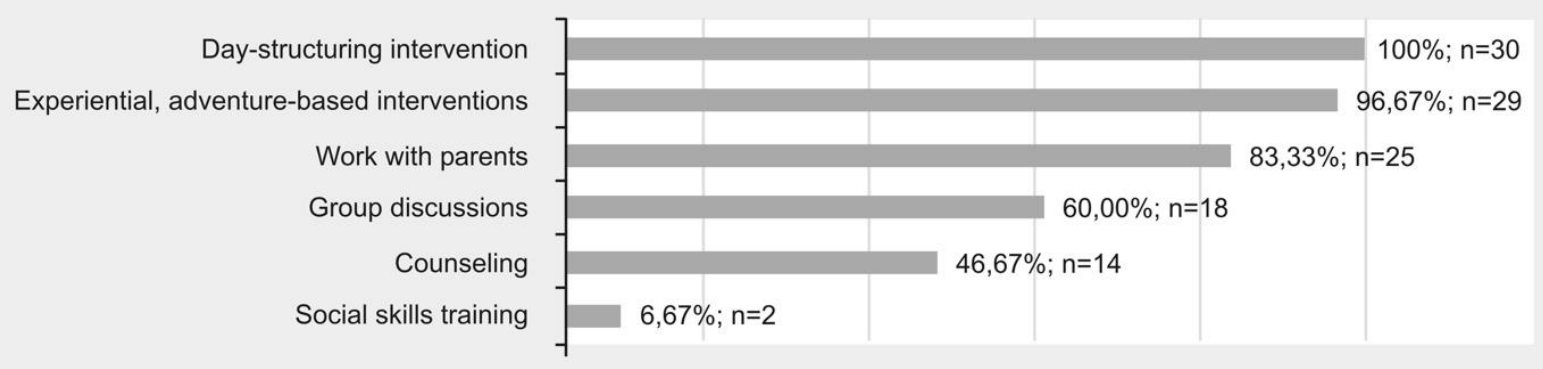

Figure 3. Participation in social therapy interventions, one or more answers possible.

It is therefore not surprising that the level of outcome for the Therapeutische Gemeinschaften was good. Of the 30 children and adolescents in the institution, the problems of two thirds were very successfully or successfully reduced. In 9 cases, more than $50 \%$ of problems (see Figure 4) could be solved; 11 cases were between 10\% and 50\% successful; and only 10 cases (one third) showed no success (see also Baur, Finkel, Hamberger, \& Kühn, 1998; Macsenaere \& Esser, 2012). The severity of the problems of the children and adolescents admitted to the institution must also be taken into account. This becomes evident when we look at the range of problems addressed at this institution (see Figure 4). 
International Journal of Child, Youth and Family Studies (2018) 9(1): 31-53

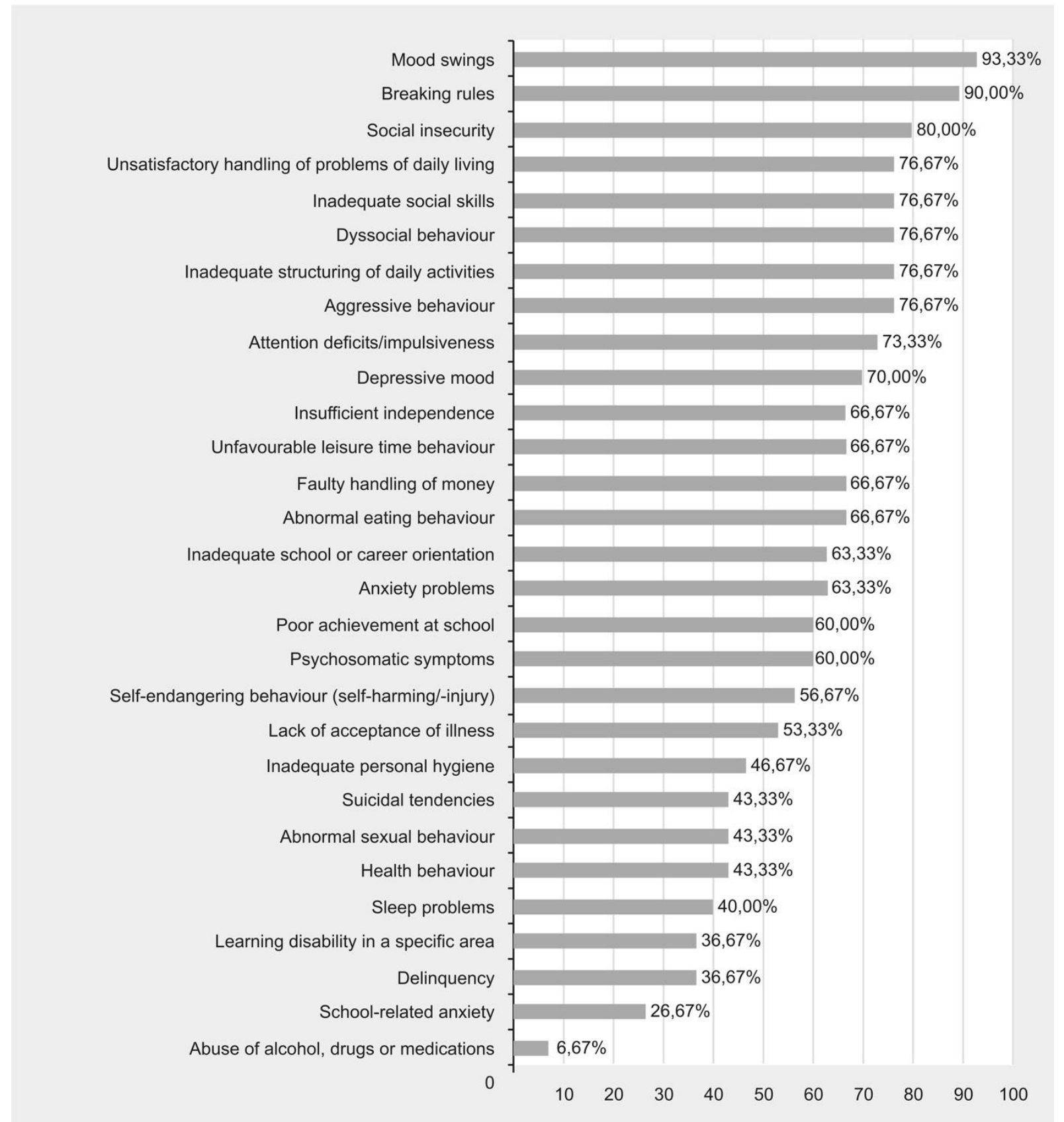

Figure 4. Problems requiring intervention (one or more answers possible, presented in \%).

We have selected only one type of symptom-oriented measurement to report in detail here. A total of 25 cases were included in the analysis of the CBCL results. On the Physical Problems subscale significant differences were found between the periods (see Figure $5 ; F(56,2$ ) $=3.089, p=.053)$. Significant differences were found between $\mathrm{t} 1$ and $\mathrm{t} 2(t=1.061, d f=51, p=$ $.025)$ and between $\mathrm{t} 1$ and $\mathrm{t} 3(t=1.080, d f=76, p=.041)$. However, no significant changes were found on the Social Problems, Schizoid-Obsessional, Attention Problems, Dyssocial Behavior, Aggressive Behavior, and Externalising subscales. This is likely due to the small sample size. 
International Journal of Child, Youth and Family Studies (2018) 9(1): 31-53

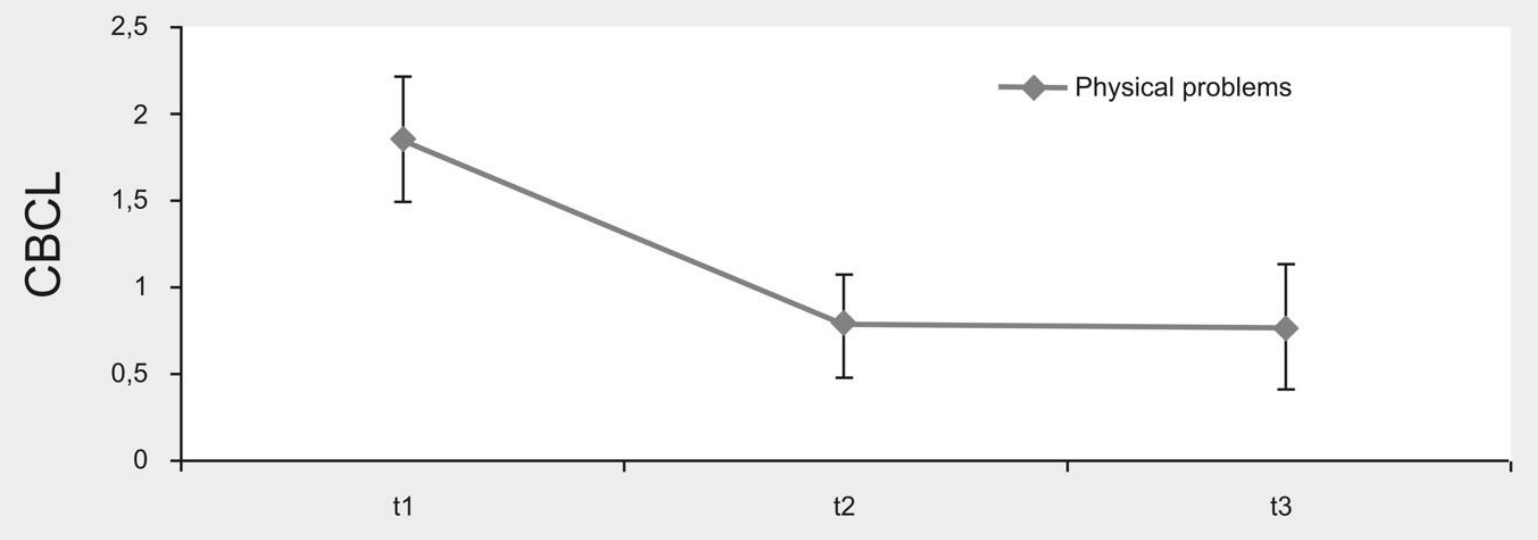

Figure 5. The temporal course of the physical problems.

However, the trauma-pedagogical programme figured particularly prominently in the results for the qualitative part of the study. The youths described painstakingly how their carers tried in everyday activities to see their clients' symptomatic behaviour against the background of their previous histories, with a trauma-informed and dialogical stance. The relationship work was done within the framework of an overall structure that provides security and authentic, participative dialogue. For example, Benedikt (names of residents have been changed to protect confidentiality) said, "Well, those people. Actually they're er really super ... The care staff are nice. I can't complain." The basic attitude of the staff at the institution was demonstrated even more clearly by the fact that the children and adolescents retained a sense of being in a safe place in the institution.

Franz put it this way, for example: "And now [I] have actually got better, that is, I held out for five or six years, so that I stayed in the therapeutic community and wasn't thrown out after a time, that is, also bad periods. And then I was almost thrown out but they kept me after all because, otherwise I might not have been able to cope at all." He went on to say that he used to be "pretty challenging"; "and now I've got better. I used to be a strenuous child ..., I flipped out almost every day. That is, that I really took everything and shot back at the carers or attacked them with a knife ... . I know that it used to be like that, but then it got good again. Now all that happens is that I start shouting or go on arguing for a long time, I always argue, for a long time, and then it (laughs) really takes a long time. But then the carers simply turn round and say, 'We'll try again in ten minutes' or 'we'll see'. Yes, and so in such situations I start shouting, but otherwise actually no more than that. ... But I say: I don't want to be like that any more, really truthfully, I wouldn't be able to do it (laughs). Otherwise I wouldn't be where I am now."

Behind this history was a well thought-out programme for thorough relationship work, as is shown by the results of the group discussions with the care workers. One member of staff described the individual sessions as follows: "To take the time to say, 'Come on, let's work out 
International Journal of Child, Youth and Family Studies (2018) 9(1): 31-53

some goals, where do we want to be, where are we now, what do you want for yourself, what do you want to achieve? But not in 20 years, we'll look at the next six months and set ourselves some small milestones - both for your school work and your social relationships. And then keep updating and reexamining that: is it still right for you, how far have we got? That demands a lot of work from the care staff, of course ... when you know that there are fewer kids around. Two of us work on a shift, then I take him off for an hour and work with him."

How far this attachment- and trauma-sensitive work has been translated into a milieu that supports development and growth became clear when we saw how the children and adolescents spoke enthusiastically about past weekends when they had spent their free time together, and their holidays. "The excursions ... We go on an excursion twice or three times - that is, on both days at the weekend ... climbing park. Or the cinema, if the weather's not so nice. Swimming. Now we can go swimming there anyway. The other day we went to a climbing park - four metres high. With a real - belay and everything. Or in the winter we go to the indoor swimming pool or other things" (Benedikt). From the experience of going on group excursions In this way a group structure of mutual acceptance and tolerance developed. In the group home Achim, for example, reported experiencing considerable respect, not only from the care workers, but also from his peers. "And all the children in the group home here, they respect me a lot".

\section{Discussion and Prospects for the Future}

The results of research on psychosocial interventions can appear to be either banal or outlandish, depending on whether they are either very similar to or contradict the practical knowledge of everyday life. It is nonetheless important, both in research and for the justification of coherent practice models, to conduct an empirical reexamination of things that have come to be taken for granted. Whether a good feeling that the helping professionals experience in their daily work is shared by the young clients for whom they are providing care is important for how they construct their programmes. It is also important to allow oneself to be inspired by results that deviate from expectations. Another point of doing research on "everyday banalities" lies in further differentiating the existing practical knowledge by gaining more precise knowledge and capturing how daily life is experienced in practice. The present study provides new insights in all these areas.

While it is well known that work on relationships is a central dimension of the process in residential youth care, it is not known what exactly such attachment- and trauma-sensitive relationship work looks like in detail or how it can be transferred to a pedagogical and therapeutic milieu in such a way that the "safe place" (Kühn, 2009; Lang, 2009) called for in trauma-pedagogical interventions can be established. In the present study not only was the core aspect of residential youth care - the handling of the relationships with the children and youth - confirmed both qualitatively and quantitatively, but numerous interview sequences revealed further that it can promote a capacity for exploration and self-empowerment (see also corrective 
International Journal of Child, Youth and Family Studies (2018) 9(1): 31-53

experiences as described by Alexander \& French, 1946; Cremerius, 1979; Grawe, 2004; Orlinsky et al., 1994).

Importantly, in contrast to many previous results (Cremerius, 1979; Grawe, 2004; Orlinsky et al., 1994), this study found that psychotherapy is not the only intervention that can bring about symptom reduction. On the contrary, both the care workers and the youths recounted having experienced scenes and moments in everyday life that brought about change (see also Gahleitner, 2016a). Thus the "therapeutic milieu" — or, to put it more exactly, the "pedagogical and therapeutic milieu" _ evidently means "expressly ... pedagogically based care programmes" (Gahleitner, 2011, p. 9). In light of this, the practice often found in residential child and youth care contexts of employing a costly child and adolescent therapist and filling the care worker posts with a badly paid and poorly qualified "ground crew" is clearly not destined to achieve the desired result. On the contrary, our results indicate that facilities employing a trauma-pedagogical approach implemented competently by the staff in their everyday interactions with their clients create the actual framework required to further the development of the children and adolescents in their care. In the facility investigated in this study, the main interest is focused on the "other 23 hours" of the day (see Trieschmann et al., 1969), and on reflection by the care workers together with the youth about the process they are sharing in their daily activities (Krumenacker, 2001), which is what gives what happens in their relationships and what happens between them its decisive effect. Many of the sequences of the interviews with the youths and their carers show how leisure-time activities can be effective in this process.

The main focus of the work is thus on the daily life and care work in the facility, which, however, was designed to construct a pedagogical and therapeutic milieu (Gahleitner, 2016a). Following the classical triangle of trauma treatment (see Gahleitner, 2011 for a summary of how this can be implemented by care workers), at the end of the youth's period in care the process culminates in integration into everyday life outside of residential care (see Figure 1). How successful the previous peer work and networking has been plays an important role in this process (Laireiter, 2009; Nestmann, 2010; Röhrle, 2001). Adolescents who have been able to build up a sizeable network of peers, who have found a way to get along with their relatives again, despite all ups and downs, and who can depend on institutions that have proved reliable for them have much better chances of successfully navigating this step.

In regard to the programme, the study shows that working on relationships within a structure that provides stability, a pedagogical and therapeutic milieu, a genuinely participative dialogue, networking and professional skills, and diversity in terms of staff, discipline, and methods, are decisive criteria of quality. If positive collaboration is possible, a social network that provides stability, everyday experiences, and leisure time experiences that create a positive atmosphere plays the greatest role in socialisation efforts (see also Brousek, 2013, 2014; Gahleitner, Radler, Gerlich, \& Hinterwallner, 2014). In order to be able to work competently in such institutions, psychosocial professionals need (a) a combination of skills in the areas of attachment and relationship work, (b) specialised knowledge in psychological trauma, (c) 
International Journal of Child, Youth and Family Studies (2018) 9(1): 31-53

provision of structure, (d) team spirit, (e) networking skills, and (f) the capacity for selfreflection and mental hygiene. If they are to work effectively, staff also need further and continuing training, supervision, peer supervision, authentic discussions within the team, and adequate opportunities for recuperation in their private lives. In sum, professional youth care workers do work that is demanding and challenging. We should give them the respect that they deserve, and the resources they need to be effective. 
International Journal of Child, Youth and Family Studies (2018) 9(1): 31-53

\section{References}

Alexander, F. G., \& French, T. M. (1946). Psychoanalytic therapy. Principles and application. New York, NY: Ronald.

AK TWG - Arbeitskreis Therapeutischer Jugendwohngruppen Berlin (Ed.). (2009). Abschlussbericht der Katamnesestudie therapeutischer Wohngruppen in Berlin: KATA$T W G$ [Final report of Catamnesis survey of therapeutic residential youth groups in Berlin KATA-TWG]. Berlin, Germany: Verlag allgemeine jugendberatung.

Baur, D., Finkel, M., Hamberger, M., \& Kühn, A. D. (1998). Leistungen und Grenzen von Heimerziehung. Ergebnisse einer Evaluationsstudie stationärer und teilstationärer Erziehungshilfen [Benefits and limitations of residential care: Results of an evaluation study of full- and part-time residential offers]. Stuttgart, Germany: Kohlhammer.

Becker, S. (2005). Pädagogisch-therapeutische Milieus - psychoanalytische Sozialarbeit und Reformpädagogik in Konvergenz [Pedagogical and therapeutic milieus - Where psychoanalytic social work and progressive education converge]. Psychosozial, 28(3 [No 101]), 119-128.

Beck-Gernsheim, E. (1981). Für eine soziale Öffnung der Bindungsforschung [Towards social transparency in attachment research]. Familiendynamik, 20(2), 193-200.

Bock, K., \& Miethe, I. (Eds.). (2010). Handbuch qualitative Methoden in der Sozialen Arbeit [Handbook of qualitative methods in social work]. Opladen, Germany: Budrich.

Böhnisch, L. (1994). Gespaltene Normalität. Lebensbewältigung und Sozialpädagogik an den Grenzen der Wohlfahrtsgesellschaft [Fractured normality: Life skills and social pedagogy on the margins of the welfare society]. Weinheim, Germany: Juventa.

Böhnisch, L. (2008). Milieubildung als pädagogisches Konzept einer lebensweltorientierten Jugendhilfe [Milieu formation as an educational concept for lifeworld-oriented youth welfare services]. In K. Grunwald \& H. Thiersch (Eds.), Praxis Lebensweltorientierter Sozialer Arbeit. Handlungszugänge und Methoden in unterschiedlichen Arbeitsfeldern (2nd ed., pp. 435-441). Weinheim, Germany: Juventa.

Bowlby, J. (1969). Attachment and loss. Vol. 1: Attachment. New York, NY: Basic Books.

Bowlby, J. (1973). Attachment and loss. Vol. 2: Separation, anxiety and anger. New York, NY: Basic Books.

Bowlby, J. (1980). Attachment and loss. Vol. 3: Loss, sadness and depression. New York, NY: Basic Books. 
International Journal of Child, Youth and Family Studies (2018) 9(1): 31-53

Brisch, K. H. (1999). Bindungsstörungen. Von der Bindungstheorie zur Therapie [Attachment disorders: From attachment theory to therapy]. Stuttgart, Germany: Klett-Cotta.

Brousek, E. (2013). Evaluation der milieutherapeutischen WG. Auswertung der CBCL/4-18 in der Milieutherapeutischen WG und in einer Vergleichsgruppe zu drei Messzeitpunkten [Evaluation of milieu therapy residential communities: Examination of the CBCL/4-18 in a milieu therapy residential community and a control group at three different points in time]. Vienna, Austria: Stadt Wien, Amt für Jugend und Familie.

Brousek, E. (2014). Evaluation der milieutherapeutischen WG. Auswertung der CBCL/4-18 in der Milieutherapeutischen WG und in einer Vergleichsgruppe ein halbes Jahr nach Projektende. Follow-up Untersuchung [Evaluation of milieu therapy residential communities: Examination of the CBCL/4-18 in a milieu therapy residential community and a control group half a year after the end of the project. Follow-up examination]. Vienna, Austria: MAG ELF.

Butollo, W., Krüsmann, M., \& Hagl, M. (1998). Leben nach dem Trauma. Über therapeutischen Umgang mit dem Entsetzen [Life after trauma: On the therapeutic treatment of shock]. Munich, Germany: Pfeiffer.

Cremerius, J. (1979). Gibt es zwei psychoanalytische Techniken? [Are there two psychoanalytic techniques?] Psyche, 32(7), 577-599.

Döpfner, M., Schmeck, K., \& Berner, W. (1994). Handbuch. Elternfragebogen über das Verhalten von Kindern und Jugendlichen. Forschungsergebnisse zur deutschen Fassung der Child Behavior Checklist (CBCL) [Handbook: Parent questionnaire about the behavior of children and adolescents. Research findings on the German version of the Child Behavior Checklist (CBCL)]. Cologne, Germany: Arbeitsgruppe Kinder-, Jugend- und Familiendiagnostik.

Drieschner, E. (2011). Bindung in familialer und öffentlicher Erziehung. Zum Zusammenhang von psychischer Sicherheit, Explorationssicherheit und früher Bildung im geteilten Betreuungsfeld [Attachment in familial upbringing and public education. On the relationship between psychological security, freedom to explore in safety, and early education in the shared care environment]. In E. Drieschner \& D. Gaus (Eds.), Liebe in Zeiten pädagogischer Professionalisierung (pp. 105-156). Wiesbaden, Germany: VS.

Eppler, N., Miethe, I., \& Schneider, A. (Eds.). (2011). Qualitative und quantitative Wirkungsforschung. Ansätze, Beispiele, Perspektiven [Qualitative and quantitative impact research: Approaches, examples, perspectives]. Opladen, Germany: Budrich.

Fischer, G., \& Riedesser, P. (1998). Lehrbuch der Psychotraumatologie [Textbook of psychotraumatology]. Munich, Germany: Reinhardt. 
International Journal of Child, Youth and Family Studies (2018) 9(1): 31-53

Fonagy, P., Gergely, G., Jurist, E. L., \& Target, M. (2002). Affect regulation, mentalization, and the development of the self. New York, NY: Other Press.

Gahleitner, S. B. (2005). Neue Bindungen wagen. Beziehungsorientierte Therapie bei sexueller Traumatisierung [Daring to make new bonds. Relationship-oriented therapy in cases of sexual traumatisation]. Munich, Germany: Reinhardt.

Gahleitner, S. B. (2011). Das Therapeutische Milieu in der Arbeit mit Kindern und Jugendlichen. Trauma- und Beziehungsarbeit in stationären Einrichtungen [The therapeutic milieu in work with children and adolescents. Trauma and relationship work in residential institutions]. Bonn, Germany: Psychiatrie-Verlag.

Gahleitner, S. B. (2016a). Milieutherapeutische und -pädagogische Konzepte [Milieu therapy and pedagogical concepts]. In W. Weiß, T. Kessler, \& S. B. Gahleitner (Eds.), Handbuch Traumapädagogik (pp. 56-66). Weinheim, Germany: Beltz.

Gahleitner, S. B. (2016b). Therapie im Kontext: Von der professionellen Beziehungsdyade zur sozialen Einbettung [Therapy in context: From the professional relationship dyad to social embeddedness]. Psychotherapie im Dialog, 17(3), 36-41. doi:10.1055/s-0042-109305

Gahleitner, S. B., Frank, C., Hinterwallner, H., Gerlich, K., \& Schneider, M. (2016). „, Ich vertrau 'ihr, ich vertrau' auch der anderen Betreuerin - und noch einer Betreuerin vertrau' ich auch-aber normalerweise selten, dass ich wem viele Geheimnisse anvertraue“. Begleitevaluation Therapeutische Gemeinschaften ["I trust her, I also trust the other caregiver, and I also trust yet another caregiver - But I rarely share many secrets with anyone." Accompanying evaluation of therapeutic residential communities]. Krems an der Donau, Austria: Donau-Universität Krems, Department für Psychotherapie und Biopsychosoziale Gesundheit.

Gahleitner, S. B., \& Homfeldt, H. G. (Eds.). (2012). Kinder und Jugendliche mit speziellem Versorgungsbedarf. Beispiele und Lösungswege für Kooperation der sozialen Dienste [Children and adolescents in need of special care. Examples of and solutions for collaboration among the social services]. Weinheim, Germany: Beltz Juventa.

Gahleitner, S. B., \& Homfeldt, H. G. (2016). Kooperation und psychosoziale Traumaarbeit [Cooperation and psychosocial trauma work]. In W. Weiß, T. Kessler, \& S. B. Gahleitner (Eds.), Handbuch Traumapädagogik (pp. 320-326). Weinheim, Germany: Beltz.

Gahleitner, S. B., Katz-Bernstein, N., \& Pröll-List, U. (2013). Das Konzept des „Safe Place“ in Theorie und Praxis der Kinder- und Jugendlichenpsychotherapie [The "safe place" concept in the theory and practice of therapy for children and adolescents]. Resonanzen, 1(2), 184204. Retrieved from http://www.resonanzen-journal.org/article/view/237/166 
International Journal of Child, Youth and Family Studies (2018) 9(1): 31-53

Gahleitner, S. B., Radler, H., Gerlich, K., \& Hinterwallner, H. (2014). Traumatisierte Kinder und Jugendliche im Hilfeprozess - brauchen wir eine Traumapädagogik? Ergebnisse aus einem Daphne-Projekt [Traumatized children and adolescents in the care process - Do we need trauma-informed practice? Results of a Daphne project]. In Die Kinderschutz-Zentren (Ed.), Wenn Kinder zum „Problemfall“ werden. Orientierung in schwierigen Hilfeprozessen (pp. 41-60). Köln, Germany: Die Kinderschutz-Zentren.

Grawe, K. (2004). Neuropsychotherapie [Neuropsychotherapy]. Göttingen, Germany: Hogrefe.

Grossmann, K., \& Grossmann, K. E. (2004). Bindungen. Das Gefüge psychischer Sicherheit [Relationships: The fabric of psychological security]. Stuttgart, Germany: Klett-Cotta.

Grossmann, K. E., \& Grossmann, K. (2001). Das eingeschränkte Leben. Folgen mangelnder und traumatischer Bindungserfahrungen [The limited life: Consequences of insufficient and traumatic bonding experiences]. In K. Gebauer \& G. Hüther (Eds.), Kinder brauchen Wurzeln. Neue Perspektiven für eine gelingende Entwicklung (pp. 35-63). Ostfildern, Germany: Patmos.

Haggerty, R. J., Roghmann, K. J., \& Pless, I. B. (1975). Child health and the community. New York, NY: Wiley.

Hart, A. (2006). Die alltäglichen kleinen Wunder. Bindungsorientierte Therapie zur Förderung der psychischen Widerstandsfähigkeit (Resilienz) von Pflege- und Adoptivkindern [Small everyday miracles: Relationship-oriented therapy to promote the mental resilience of foster and adopted children]. In K. H. Brisch \& T. Hellbrügge (Eds.), Kinder ohne Bindung, Deprivation, Adoption und Psychotherapie (pp. 190-222). Stuttgart, Germany: Klett Cotta.

Hölling, H., Schlack, R., Petermann, F., Ravens-Sieberer, U., \& Mauz, E. (2014). Psychische Auffälligkeiten und psychosoziale Beeinträchtigungen bei Kindern und Jugendlichen im Alter von 3 bis 17 Jahren in Deutschland - Prävalenz und zeitliche Trends zu 2 Erhebungszeitpunkten (2003-2006 und 2009-2012). Ergebnisse der KiGGS-Studie - Erste Folgebefragung (KiGGS Welle 1) [Psychological abnormalities and psychosocial impairments in children and adolescents aged 3 to 17 in Germany - Prevalence and trends over time during 2 data collection periods (2003-2006 and 2009-2012). Results of the KiGGS study - First follow-up survey (KiGGS Wave 1)]. BundesgesundheitsblattGesundheitsforschung - Gesundheitsschutz, 57(7), 807-819. Retrieved from http://edoc.rki.de/oa/articles/re9wG5xBftbdM/PDF/23snHyPgg8sPo.pdf

Keupp, H. (1997). Ermutigung zum aufrechten Gang [Encouragement to walk tall]. Tübingen, Germany: DGVT. 
International Journal of Child, Youth and Family Studies (2018) 9(1): 31-53

Krüger, A., \& Reddemann, L. (2007). Psychodynamisch Imaginative Traumatherapie für Kinder und Jugendliche. PITT-KID - Das Manual [Psychodynamic and imaginative trauma therapy for children and adolescents. PITT-KID - The manual]. Stuttgart, Germany: KlettCotta.

Krumenacker, F.-J. (2001). Entwicklung beginnt mit Pädagogen: Über milieutherapeutische Beziehungsgestaltung [Development begins with educators: About milieu therapy relationship management]. In St. Theresienhaus (Ed.), Beziehungsarbeit in der Jugendhilfe. Rahmenbedingungen und Gestaltungsmöglichkeiten (pp. 13-50). Bremen, Germany: Amberg.

Kühn, M. (2009). „Macht eure Welt endlich wieder mit zu meiner!“” Anmerkungen zum Begriff der Traumapädagogik ["Make your world my world again, at last!" Notes on the concept of trauma-informed education]. In J. Bausum, L. Besser, M. Kühn, \& W. Weiß (Eds.), Traumapädagogik. Grundlagen, Arbeitsfelder und Methoden für die pädagogische Praxis (pp. 23-35). Weinheim, Germany: Juventa.

Laireiter, A.-R. (2009). Soziales Netzwerk und Soziale Unterstuitzung [Social network and social support]. In K. Lenz \& F. Nestmann (Eds.), Handbuch Persönliche Beziehungen (pp. 7599). Weinheim, Germany: Juventa.

Lang, B. (2009). Stabilisierung und (Selbst-)Fürsorge für pädagogische Fachkräfte als institutioneller Auftrag [Stabilization and (self) care for educational professionals as an institutional mandate]. In J. Bausum, L. U. Besser, M. Kühn, \& W. Weiß (Eds.), Traumapädagogik. Grundlagen, Arbeitsfelder und Methoden für die pädagogische Praxis (pp. 211-219). Weinheim, Germany: Juventa.

Lebowitz, L., Harvey, M. R., \& Herman, J. L. (1993). A stage-by-dimension model of recovery from sexual trauma. Journal of Interpersonal Violence, 8(3), 378-391. doi:10.1177/088626093008003006

Macsenaere, M., \& Esser, K. (2012). Was wirkt in der Erziehungshilfe? Wirkfaktoren in Heimerziehung und anderen Hilfearten [What educational support measures are successful? Impact factors in residential care settings and other forms of support]. Munich, Germany: Reinhardt.

Mayring, P. (2000). Qualitative Inhaltsanalyse [Qualitative content analysis]. Forum Qualitative Sozialforschung, 1(2), Art. 20. doi:10.17169/fqs-1.2.1089

Mayring, P. (2002). Einführung in die qualitative Sozialforschung. Eine Anleitung zu qualitativem Denken [Introduction to qualitative social research: A guideline for qualitative thinking] (5th ed.). Weinheim, Germany: Beltz. 
International Journal of Child, Youth and Family Studies (2018) 9(1): 31-53

Mayring, P., \& Gahleitner, S. B. (2010). Qualitative Inhaltsanalyse [Qualitative content analysis]. In K. Bock \& I. Miethe (Eds.), Handbuch qualitative Methoden in der Sozialen Arbeit [Handbook of qualitative methods in social work] (pp. 295-304). Opladen, Germany: Budrich.

Müller, H.-R. (1999). Zum Verhältnis von Erziehung und Therapie in der Heimerziehung [On the relationship between education and therapy in residential care settings]. In H. E. Colla, T. Gabriel, S. Millham, S. Müller-Teusler, \& M. Winkler (Eds.), Handbuch Heimerziehung und Pflegekinderwesen in Europa (pp. 405-413). Neuwied, Germany: Luchterhand.

Nestmann, F. (2010). Soziale Unterstützung - Social Support. In W. Schröer \& C. Schweppe (Eds.), Enzyklopädie Erziehungswissenschaft Online (pp. 1-39). Weinheim, Germany: Juventa.

Orlinsky, D. E., Grawe, K., \& Parks, B. K. (1994). Process and outcome in psychotherapy: Noch einmal. In A. E. Bergin \& S. L. Garfield (Eds.), Handbook of psychotherapy and behavior change (4th ed., pp. 270-376). New York, NY: Wiley.

Otto, H.-U., Albus, S., Polutta, A., Schrödter, M., \& Ziegler, H. (Eds.). (2007). Zum aktuellen Diskurs um Ergebnisse und Wirkungen im Feld der Sozialpädagogik und SozialarbeitLiteraturvergleich nationaler und internationaler Diskussion [On the current discourse about results and impacts in the fields of social pedagogy and social work: A literature review of national and international discussions]. Berlin, Germany: AGJ.

Pauls, H. (2006). Standards, evidenzbasierte Praxis, Praxisforschung: Was können wir tun? [Standards, evidence-based practice, practice research: What can we do?] Klinische Sozialarbeit, 2 (Online special ed.), 38-39. Retrieved from https://www.dgsa.de/fileadmin/Dokumente/Sektionen/Klinische_Sozialarbeit/klinsa_special 2006.pdf

Pauls, H. (2012). Generalistische und Klinische (Fach-)Sozialarbeit [Generalist and clinical (specialized) social work]. Klinische Sozialarbeit, 8(1), 4-6. Retrieved from https://www.dgsa.de/fileadmin/Dokumente/Sektionen/Klinische_Sozialarbeit/KlinSA_2012 8-1_Generalisierung-und-Klinische-Fachsozialarbeit.pdf

Perry, B. D., \& Pollard, R. A. (1998). Homeostasis, stress, trauma and adaptation. A neurodevelopmental view of childhood trauma. Child and Adolescent Psychiatric Clinics of North America, 7(1), 33-51.

Redl, F. (1971). Erziehung schwieriger Kinder. Beiträge zu einer psychotherapeutisch orientierten Pädagogik [Education of difficult children: Contributions to psychotherapyoriented education]. Munich, Germany: Piper. 
International Journal of Child, Youth and Family Studies (2018) 9(1): 31-53

Richter, M., Hurrelmann, K., Klocke, A., Melzer, W., \& Ravens-Sieberer, U. (Eds.). (2008). Gesundheit, Ungleichheit und jugendliche Lebenswelten. Ergebnisse der zweiten internationalen Vergleichsstudie im Auftrag der Weltgesundheitsorganisation WHO [Health, inequality, and adolescent lifeworlds: Results of the second international comparative study commissioned by the World Health Organization (WHO)]. Weinheim, Germany: Juventa.

Röhrle, B. (2001). Soziale Netzwerke [Social networks]. In D. H. Rost (Ed.), Handwörterbuch Pädagogische Psychologie [Concise dictionary of educational philosophy] (2nd ed., pp. 657-668). Weinheim, Germany: PVU.

Schleiffer, R., \& Gahleitner, S. B. (2010). Schwierige Klientel oder schwierige Helfende? Konsequenzen desorganisierter Bindungsmuster für die psychosoziale Arbeit [Difficult clients or difficult helpers? - Consequences of disorganized attachment patterns for psychosocial work]. In S. B. Gahleitner \& G. Hahn (Eds.), Klinische Sozialarbeit. Gefährdete Kindheit - Risiko, Resilienz und Hilfen (pp. 197-213). Bonn, Germany: Psychiatrie-Verlag.

Schmid, M. (2007). Psychische Gesundheit von Heimkindern. Eine Studie zur Prävalenz psychischer Störungen in der stationären Jugendhilfe [Mental health of institutionalized children: A study on the prevalence of mental disorders in residential youth welfare services]. Weinheim, Germany: Juventa.

Schmid, M. (2010). Psychisch belastete Heimkinder - eine besondere Herausforderung für die Schnittstelle zwischen Klinischer Sozialarbeit und Kinder- und Jugendpsychiatrie/psychotherapie [Mental strain in institutionalized children - A particular challenge for the interface between clinical social work and child and adolescent psychiatry/psychotherapy]. In S. B. Gahleitner \& G. Hahn (Eds.), Klinische Sozialarbeit. Gefährdete Kindheit - Risiko, Resilienz und Hilfen (pp. 113-121). Bonn, Germany: Psychiatrie-Verlag.

Sgolik, V., \& Buchholz-Graf, W. (2010). Das Leben ehemaliger Heimkinder: Eine katamnestische Befragung von Jugendlichen und jungen Erwachsenen im Raum Regensburg [The life of formerly institutionalized children: A catamnestic survey of adolescents and young adults in the Regensburg region]. Das Jugendamt - Zeitschrift für Jugendhilfe und Familienrecht, 83(3), 106-111.

Solomon, J., \& George, C. C. (2011). Disorganized attachment and caregiving. New York, NY: Guilford.

Sommerfeld, P., \& Hüttemann, M. (Eds.). (2007). Evidenzbasierte Soziale Arbeit. Nutzung von Forschung in der Praxis [Evidence-based social work: Practical application of research]. Baltmannsweiler, Germany: Schneider. 
International Journal of Child, Youth and Family Studies (2018) 9(1): 31-53

Thyen, U., \& Scriba, P. C. (Eds.). (2007). Ergebnisse des Kinder- und Jugendgesundheitssurveys (KiGGS) 2003-2006 [Results of the German Health Interview and Examination Survey for Children and Adolescents (KiGGS) 2003-2006] (special issue). Bundesgesundheitsblatt Gesundheitsforschung - Gesundheitsschutz, 50(5/6).

Trieschmann, A. E., Whittaker, J. K., \& Brendtro, L. K. (1969). The other 23 hours: Child care work in a therapeutic milieu. Chicago, IL: Aldine.

Van IJzendoorn, M. H., Schuengel, C., \& Bakermans-Kronenburg, M. J. (1999). Disorganized attachment in early childhood: Meta-analysis of precursors, concomitants, and sequelae. Development and Psychopathology, 11(2), 225-249. Retrieved from https://openaccess.leidenuniv.nl/bitstream/handle/1887/1530/168_212.pdf

Weiß, W. (2016). Philipp sucht sein Ich. Zum pädagogischen Umgang mit Traumata in den Erziehungshilfen [Philipp is looking for his self: On the educational approach to trauma in educational support services] (8th ed.). Weinheim, Germany: Beltz Juventa.

Wintersperger, S. (2006). Wann ist das Trauma zu Ende? Wege und Ziele in der Traumatherapie [When does trauma end? Approaches and objectives in trauma therapy]. Imagination, 28(2), $39-48$.

Witzel, A. (1982). Verfahren der qualitativen Sozialforschung. Überblick und Alternativen [Methods of qualitative social research: Overview and alternatives]. Frankfurt, Germany: Campus.

Witzel, A. (2000). Das problemzentrierte Interview [The problem-centered interview]. Forum Qualitative Sozialforschung, 1(1), Art. 22. doi:10.17169/fqs-1.1.1132

Yehuda, R. (1998). Neuroendocrinology of trauma and posttraumatic stress disorder. In R. Yehuda (Ed.), Psychological trauma (pp. 97-132). Washington, DC: American Psychiatric Press.

Ziegenhain, U., \& Fegert, J. M. (2012). Frühkindliche Bindungsstörungen [Early childhood attachment disorders]. In J. M. Fegert, C. Eggers, \& F. Resch (Eds.), Psychiatrie und Psychotherapie des Kindes- und Jugendalters (2nd ed., pp. 938-947). Heidelberg, Germany: Springer.

Ziegenhain, U., \& Gloger-Tippelt, G. (2013). Bindung und Handlungssteuerung als frühe emotionale und kognitive Voraussetzung von Bildung [Relationships and action control as an early emotional and cognitive requirement of education]. Zeitschrift für Pädagogik, 59(6), 793-802. 